\title{
Synthesis and Cyclic Voltammetry Studies of 3,4-Methylenedioxymethamphetamine (MDMA) Human Metabolites
}

\author{
Carla Macedo, ${ }^{a}$ Paula Sério Branco, ${ }^{*}, a$ Luísa Maria Ferreira, ${ }^{a}$ Ana Maria Lobo, ${ }^{a}$ João \\ Paulo Capela, ${ }^{b}$ Eduarda Fernandes, ${ }^{c}$ Maria de Lourdes Bastos, ${ }^{b}$ and Felix Carvalho ${ }^{b}$
}

${ }^{a}$ REQUIMTE/CQFB, Departamento de Química, FCT, Universidade Nova de Lisboa, 2829-516 Caparica, Portugal, ${ }^{b}$ REQUIMTE, Departamento de Toxicologia, and ${ }^{c} R E Q U I M T E$, Departamento de Química-Física, Faculdade de Farmácia da Universidade do Porto, 4099-1030, Porto, Portugal

(Received July 6, 2006; Accepted October 27, 2006)

\begin{abstract}
3,4-Methylenedioxymethamphetamine (MDMA or "Ecstasy") is a widely abused, psychoactive recreational drug. There are growing evidences that the MDMA neurotoxic profile may be highly dependent on its hepatic metabolism. MDMA metabolism leads to the production of highly reactive derivates, namely catechols, catechol thioethers, and quinones. In this study the electrochemical oxidation-reduction processes of MDMA human metabolites, obtained by chemical synthesis, were evaluated by cyclic voltammetry based on an electrochemical cell with a glassy carbon working electrode. The toxicity of $\alpha$-methyldopamine $(\alpha$-MeDA), $N$-methyl- $\alpha$ methyldopamine (N-Me- $\alpha$-MeDA) and 5-(glutathion- $S$-yl)- $\alpha$-methyldopamine [5-(GSH)- $\alpha$-MeDA] to rat cortical neurons was then correlated with their redox potential. The obtained data demonstrated that the lower oxidation potential observed for the catecholic thioether of $\alpha$-MeDA correlated with the higher toxicity of this adduct. This accounts for the use of voltammetry data in predicting the toxicity of MDMA metabolites.
\end{abstract}

Key words — 3,4-Methylenedioxymethamphetamine, Neurotoxicity, Cyclic voltammetry, Metabolites, Rat cortical neurons

\section{INTRODUCTION}

The research in the area of drug abuse is mainly focused in its direct or indirect effects on receptors and transmitters ${ }^{1)}$ and less attention has been given to the putative chemical reactivity of their metabolic products. However, there are overwhelming evidences indicating that metabolites are often crucial participants in the action of drugs and toxins.

The ring-substituted amphetamines, 3,4Methylenedioxymethamphetamine (MDMA), 1 and methylenedioxyam-phetamine (MDA), 2 are well established serotonergic neurotoxicants. ${ }^{2,3)}$ MDMA, also known as "Ecstasy," is a widely abused psychoactive recreational drug associated with acute and long-term toxic effects. MDA, a well characterized metabolite of MDMA, has also been used as a drug of abuse. Various studies

\footnotetext{
*To whom correspondence should be addressed: REQUIMTE/ CQFB, Departamento de Química, FCT, Universidade Nova de Lisboa, 2829-516 Caparica, Portugal. Tel.: +351-212948300; Fax: +351-212948550; E-mail: psb@dq.fct.unl.pt
}

in laboratory animals and humans have been demonstrating that the exposure to MDMA may elicit long-term changes in the neurochemistry and behavior. These changes result from the selective neurotoxicity to the 5-hydroxytryptamine (5-HT) containing axon terminals. ${ }^{4}$ )

Systemic metabolism seems important for the neurotoxic response since, in some animal studies, direct injection of MDA or MDMA into the brain did not cause long-term 5-HT deficits. ${ }^{5-7)}$ The metabolism of MDMA and MDA starts with $O$ demethylenation to $N$-methyl- $\alpha$-methyldopamine (N-Me- $\alpha$-MeDA), 3 and $\alpha$-methyldopamine $(\alpha$ MeDA), 4 respectively, both of which are catecholamines that can undergo oxidation to the corresponding ortho-quinones 5 and $\mathbf{6}$ (for detailed insights on MDMA metabolism see Fig. 1). ${ }^{8,9)}$ These quinones are highly active redox molecules, which can enter redox cycles with their semiquinone radicals, leading to formation of reactive oxygen species (ROS) and reactive nitrogen species (RNS). ${ }^{10,11)}$ The toxicity of these metabolites has been corre- 


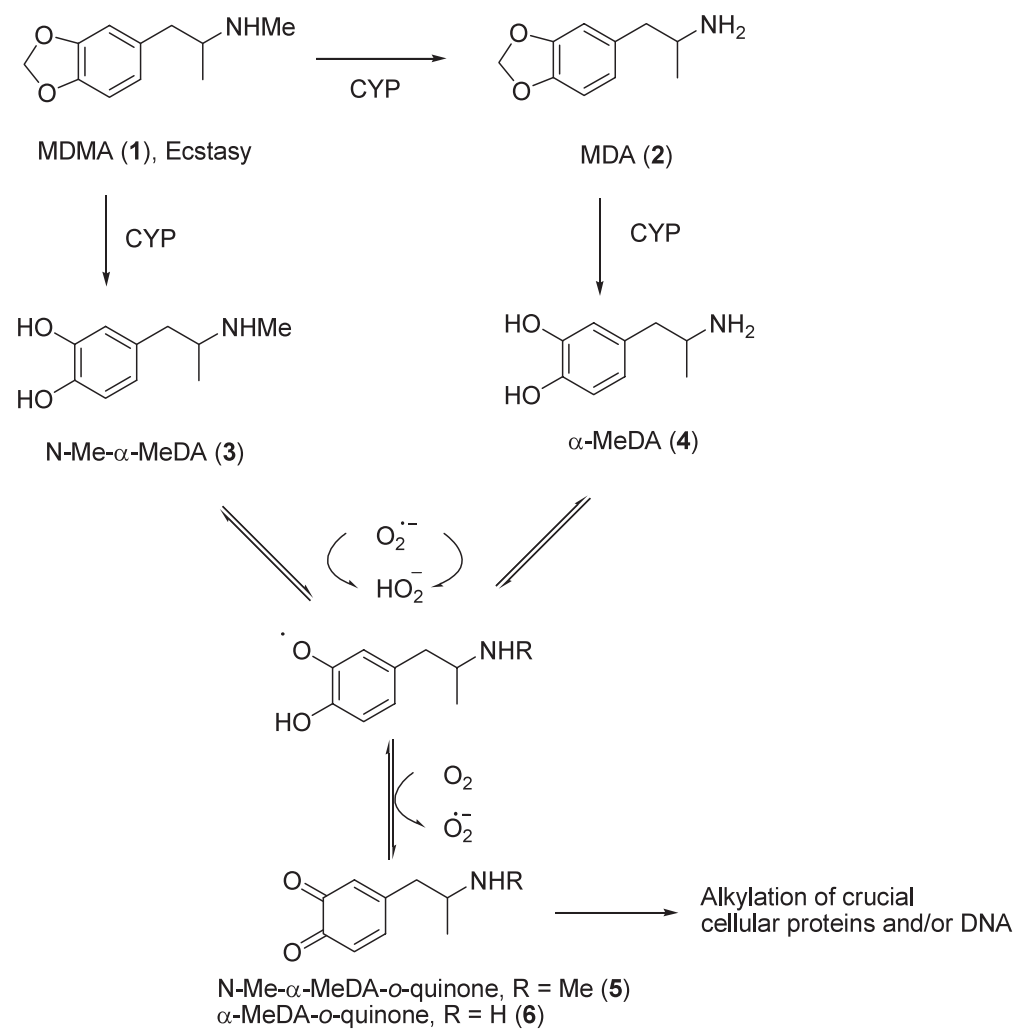

Fig. 1. Proposed Pathway for MDMA Metabolism Leading to Reactive Intermediates Capable of Alkylating Cellular Components

lated with electron transfer (ET), ROS formation and consequent oxidative stress (OS). ${ }^{12,13)}$ A cyclic voltammetry study on the oxidation-reduction behavior of bioactive catecholamines ${ }^{14,15)}$ showed the straightforward formation of the corresponding $o$ quinones via electro-oxidation (a two electron transfer process). These $o$-quinones can readily undergo reduction, indicating the potential for ET occurrence in vivo. Alternatively, the reactive $o$-quinone intermediates are Michael acceptors, and cellular damage can occur through alkylation of crucial cellular proteins and/or DNA. In the presence of other bionucleophiles, as GSH, o-quinones may conjugate to form adducts. These conjugates remain redox active being in turn readily oxidized to the corresponding quinone-adducts, which are susceptible to an addition of a second nucleophile molecule. ${ }^{16)}$

Our group has previously evaluated the toxicity of MDMA and three of its metabolites, obtained by synthesis, namely N-Me- $\alpha$-MeDA, $\alpha$ MeDA and 5-(glutathion- $S$-yl)- $\alpha$-methyldopamine [5-(GSH)- $\alpha$-MeDA], 7, in rat cortical neuronal serum free cultures under normal $\left(36.5^{\circ} \mathrm{C}\right)$ and hyperthermic $\left(40^{\circ} \mathrm{C}\right)$ conditions. ${ }^{17)}$ It was shown that these metabolites are more neurotoxic than the parent compound MDMA, being 5-(GSH)- $\alpha$ -
MeDA the most toxic. We have also previously demonstrated that the metabolism is important for MDMA-induced toxicity to peripheral organs. ${ }^{18-20)}$

The underlying mechanisms of MDMA and MDA-induced neurotoxicity, namely the toxic effects mediated by its metabolite(s), remain to be completely elucidated. Herein we present cyclic voltammetry studies that provide evidence for a correlation between the toxicity of MDMA and MDAmetabolites and their redox potential.

\section{MATERIALS AND METHODS}

Reagents and Apparatuses $-N$-Acetylcysteine (NAC), GSH, mushroom tyrosinase (4400 units/mg) and other chemicals were obtained from Sigma-Aldrich ${ }^{\circledR}$ (Steinheim, Germany). MDMA ( $\mathrm{HCl}$ salt) was extracted and purified from high purity MDMA tablets that were provided by the Portuguese's Criminal Police Department. The obtained salt was pure and fully characterized by NMR and mass spectrometry methodologies.

Solvents were dried by standard methods ${ }^{21)}$ and distilled before use. Analytical thin-layer chromatography was conducted on Merck (Darmstadt, 
Germany) Kieselgel 60, F254 silica gel $0.2 \mathrm{~mm}$ thick plates; column chromatography was performed on Merck Kieselgel 60 (240-400 nm) silica gel or reverse-phase RP-18 modified silica. Melting points were recorded on a Reichert-Thermovar hot stage apparatus and are reported uncorrected. InfRaRed (IR) spectra were recorded on a Perkin Elmer (Beaconsfield, UK) Spectrum 1000 as potassium bromide $(\mathrm{KBr})$ pellets or as film over sodium chloride $(\mathrm{NaCl})$ windows. UV/vis spectra were recorded between 200 and $500 \mathrm{~nm}$ on a Thermo Electron Helios $\gamma$. Proton and carbon nuclear magnetic resonance spectra $\left({ }^{1} \mathrm{H}\right.$ - and ${ }^{13} \mathrm{C}$-NMR $)$ were recorded on a Bruker (Wissembourg, France) ARX 400 spectrometer at 400 and $100.62 \mathrm{MHz}$ respectively. Chemical shifts are expressed in ppm, downfield from trimethylsilyl (TMS, $\delta=0$ ) as an internal standard; $J$-values are given in Hz. The exact attribution of NMR signals was preformed using two dimensional NMR experiments. Low resolution mass spectra were acquired with a Micromass (Manchester, UK) GC-TOF Gas Chromatogra-phy Time-of-fly (GCT) mass spectrometer. HPLC was conducted on a Merck Hitachi (Tokyo, Japan) system consisting of an L-7100 pump, a Rheodyne type injector, a D-7000 interface, and an L7450A diode array spectrometric detector. Cyclic voltammograms were run at room temperature on an Autolab (Utrecht, Netherlands) PGSTAT12 potentiostat connected to a conventional three-electrode cellassembly (saturated calomel electrode (SCE) as reference, Pt wire as counter electrode and glassy carbon as working electrode).

\section{Chemical Synthesis}

Hydrobromide salts of $N$-methyl- $\alpha$-methyldopamine (3) and $\alpha$-methyldopamine (4). N-Me$\alpha$-MeDA.HBr and $\alpha$-MeDA.HBr were prepared following the procedures of Borgman ${ }^{22)}$ and Pizarro ${ }^{23)}$ starting from the corresponding benzaldehyde and nitroethane.

Hydrobromide salt of 1-( $3^{\prime}, 4^{\prime}, 5^{\prime}$-Trihydroxyphenyl)-2-aminopropane (5-OH- $\alpha$-MeDA, 13) was prepared following the previously procedure starting from the corresponding 3,4,5trimethoxybenzaldehyde and nitroethane.

Trans-1-( $3^{\prime}, 4^{\prime}, 5^{\prime}$-trimethoxyphenyl)-2-nitropropene. Obtained in $50 \%$ yield. Recristalized from ethanol/water, mp $97-98^{\circ} \mathrm{C}$ [lit. ${ }^{24)} 94^{\circ} \mathrm{C}$ ]; IV $\left(\mathrm{KBr}, v_{\max } \mathrm{cm}^{-1}\right): 1645,1580,1512 ;{ }^{1} \mathrm{H}-\mathrm{NMR}$ $(\mathrm{CDCl} 3, \delta): 2.49\left(3 \mathrm{H}, \mathrm{s}, \mathrm{CH}_{3}\right), 3.89\left(6 \mathrm{H}, \mathrm{s}, \mathrm{OCH}_{3}\right)$, $3.91\left(3 \mathrm{H}, \mathrm{s}, \mathrm{OCH}_{3}\right), 6.66(2 \mathrm{H}, \mathrm{s}, \mathrm{ArH}), 8.03(1 \mathrm{H}, \mathrm{s}$,
$\mathrm{HC})$.

1-(3', $4^{\prime}, 5^{\prime}$-Trimethoxyphenyl)-2-aminopropane hydrochloride. To a solution of $\mathrm{LiAlH}_{4}$ $(0.4 \mathrm{~g}, 0.01 \mathrm{~mol})$ in dry tetrahydrofuran (THF, $10 \mathrm{ml}$ ) was added dropwise a solution of trans1-( $3^{\prime}, 4^{\prime}, 5^{\prime}$-trimethoxyphenyl)-2-nitropropene (1 g, $\left.3.97 \times 10^{-3} \mathrm{~mol}\right)$ in THF $(10 \mathrm{ml})$. The solution was refluxed for $3 \mathrm{hr}$ after which the excess of $\mathrm{LiAlH}_{4}$ was destroyed by slow addition of $2 \mathrm{ml}$ of water followed by $2 \mathrm{ml}$ of aqueous $15 \% \mathrm{NaOH}$ and finally $5 \mathrm{ml}$ of water. The mixture was filtered and the residue washed with THF. The solution was dried with anhydrous $\mathrm{Na}_{2} \mathrm{SO}_{4}$ and evaporated to dryness. The yellow oil was dissolved in hexane and the compound precipitated by freezing. The product was obtained as its hydrochloride salt by precipitation of the salt by slow addition of an $\mathrm{HCl}$ dry ethyl ether solution: $\mathrm{mp} 221-223^{\circ} \mathrm{C}$ (lit. ${ }^{25}$ ) 216-217 $\left.{ }^{\circ} \mathrm{C}\right)$, IV (KBr, $\left.v_{\max } \mathrm{cm}^{-1}\right)$ : 3400, 2938, 1587, 1514, 1321，1246，1136, 1092; ${ }^{1} \mathrm{H}-\mathrm{NMR}$ $\left(\mathrm{CDCl}_{3}, \delta\right): 1.14\left(3 \mathrm{H}, \mathrm{d}, J=6.2, \mathrm{CH}_{3}\right), 2.42(1 \mathrm{H}$, $\mathrm{dd}, J=13.0$ and $\left.8.4, \mathrm{CH}_{2}\right), 2.68(1 \mathrm{H}, \mathrm{dd}, J=13.0$ and 4.8, $\left.\mathrm{CH}_{2}\right), 3.19-3.14(1 \mathrm{H}, \mathrm{m}, \mathrm{CH}), 3.83(3 \mathrm{H}, \mathrm{s}$, $\left.\mathrm{OCH}_{3}\right), 3.85\left(6 \mathrm{H}, \mathrm{s}, \mathrm{OCH}_{3}\right), 6.41(2 \mathrm{H}, \mathrm{s}, \mathrm{ArH})$.

5-OH- $\alpha$-MeDA (13). A solution of $1-\left(3^{\prime}, 4^{\prime}, 5^{\prime}\right.$ trimethoxyphenyl)-2-aminopropane hydrochloride $\left(0.1 \mathrm{~g}, 3.82 \times 10^{-4} \mathrm{~mol}\right)$ in $10 \mathrm{ml}$ of $48 \% \mathrm{HBr}$ was degassed for one hour, warmed to $125^{\circ} \mathrm{C}$ for $3 \mathrm{hr}$ and finally stirred $1 \mathrm{hr}$ at room temperature. The product purification was performed by reverse-phase RP-18 modified silica column chromatography with water. The solution was concentrated to dryness. The air sensitive 1-( $3^{\prime}, 4^{\prime}, 5^{\prime}$-trihydroxiphenyl)-2aminopropane hydrobromide was obtained as a orange oil $(0.06 \mathrm{~g})$ in $60 \%$ yield. ${ }^{1} \mathrm{H}-\mathrm{NMR}\left(\mathrm{D}_{2} \mathrm{O}, \delta\right)$ : $1.16\left(3 \mathrm{H}, \mathrm{d}, J=6.5, \mathrm{CH}_{3}\right), 2.58(1 \mathrm{H}, \mathrm{dd}, J=13.9$ and 7.7, $\left.\mathrm{CH}_{2}\right), 2.66(1 \mathrm{H}, \mathrm{dd}, J=13.9$ and 6.7 , $\left.\mathrm{CH}_{2}\right), 3.45-3.39(1 \mathrm{H}, \mathrm{m}, \mathrm{CH}), 6.29$ (2H, s, ArH); ${ }^{13} \mathrm{C}-\mathrm{RMN}\left(\mathrm{D}_{2} \mathrm{O}, \delta\right): 17.6\left(\mathrm{CH}_{3}\right), 39.6\left(\mathrm{CH}_{2}\right), 49.1$ $(\mathrm{CH}), 109.6\left(\mathrm{C}_{\mathrm{Ar} 2^{\prime}+6^{\prime}}\right), 128.5\left(\mathrm{C}_{\mathrm{Ar}^{\prime}+3^{\prime} / 5^{\prime}}\right), 131.3$ $\left(\mathrm{C}_{\mathrm{Ar}^{\prime} / 5^{\prime}}\right), 145.5\left(\mathrm{C}_{\mathrm{Ar}^{\prime}}\right)$; MS (Field desorption): $m / z$ 184.1030 $\left(\mathrm{MH}^{+}\right)$calculated for $\mathrm{C}_{9} \mathrm{H}_{14} \mathrm{NO}_{3}$ : 184.0974 .

Synthesis of the conjugated adducts of $N$-methyl- $\alpha$-methyldopamine and $\alpha$-methyldopamine with GSH and NAC. 5-(GSH)$\alpha$-MeDA (7), 5-(glutathion- $S$-yl)- $N$-methyl- $\alpha$ methyldopamine hydrobromide [5-(GSH)-N-Me$\alpha$-MeDA, (8)], 5-( $N$-acetylcystein- $S$-yl)- $\alpha$-methyldopamine hydrobromide [5-(NAC)- $\alpha$-MeDA, (9)] and 5-( $N$-acetylcystein- $S$-yl)- $N$-methyl- $\alpha$ methyldopamine hydrobromide [5-(NAC)-N- 
Me- $\alpha$-MeDA, (10)] were prepared according to previously published methods ${ }^{26,27)}$ with the modifications reported bellow.

5-(GSH)- $\alpha$-MeDA (7) and 2-(Glutathion- $S$ yl)- $\alpha$-methyldopamine hydrobromide [2-(GSH)$\alpha$-MeDA, (11)]. To a solution of $\mathbf{4}$ as hydrobromide salt $\left(0.020 \mathrm{~g}, 8.06 \times 10^{-5} \mathrm{~mol}\right)$ in sodium phosphate buffer $(80 \mathrm{ml}, \mathrm{pH} 7.4,50 \mathrm{mM})$ at $25^{\circ} \mathrm{C}$ it was added mushroom tyrosinase ( 8000 units, $100 \mathrm{U} / \mathrm{ml}$ buffer). The solution became red, indicating the formation of $o$-quinone. GSH $\left(0.124 \mathrm{~g}, 4.03 \times 10^{-4} \mathrm{~mol}\right)$ was added and the solution red color changed with time to yellow (1 hr). The solution was carefully concentrated by rotary evaporation at room temperature and diluted in $1 \mathrm{ml}$ of water. The product's purification was performed by reverse-phase RP-18 modified silica column chromatography, first with water $(150 \mathrm{ml})$ and then the product separated using $10 \times 7.5 \mathrm{ml}$ of formic acid/water/methanol (1:49:50). Each fraction was checked for the presence of adduct using a UV/vis detector. Fractions containing maxima at 264 and $294 \mathrm{~nm}$ were separated and lyophilized to dryness. Product $7\left(2.7 \times 10^{-2} \mathrm{~g}\right)$ was obtained as an oil in $60 \%$ yield and the adduct $\mathbf{1 1}$ $\left(1.6 \times 10^{-3} \mathrm{~g}\right)$ also as an oil in $3.1 \%$ yield. The compound's purity was checked by HPLC using a LiChrospher 100 RP-18 column, with two mobile phase solvents. Solvent A was prepared by adding concentrated trifluoroacetic acid (TFA) to deionized water until $\mathrm{pH}$ was 2.15 . Solvent $\mathrm{B}$ was prepared by adding TFA to a 1:1 mixture of acetonitrile (MeCN) and deionized water until $\mathrm{pH} 2.15$. The following mobile phase gradient was used: $0-2 \mathrm{~min}, 100 \%$ of solvent A; $2-10 \mathrm{~min}, 100-65 \%$ of solvent A; 10 20 min, $65-0 \%$ of solvent A; $20-25$ min, $100 \%$ of solvent B; $25-30$ min $100 \%$ of solvent A. The compounds 7 and $\mathbf{1 1}$ eluted in 13 and $11.7 \mathrm{~min}$ respectively. The peaks were monitored at $290 \mathrm{~nm}$. 5(GSH)- $\alpha$-MeDA (7): ${ }^{1} \mathrm{H}-\mathrm{NMR}\left(\mathrm{D}_{2} \mathrm{O}, \delta\right): 1.15(3 \mathrm{H}$, $\left.\mathrm{d}, J=6.2, \mathrm{CH}_{3}\right), 2.01-1.96(2 \mathrm{H}, \mathrm{m}, \mathrm{Glu}-\beta), 2.35$ $(2 \mathrm{H}, \mathrm{t}, J=7.1$, Glu- $\gamma), 2.64\left(2 \mathrm{H}, \mathrm{d}, J=6.6, \mathrm{CH}_{2}\right)$, 3.08-3.02 (1H, m, Cys- $\beta$ ), 3.26-3.22 (1H, m, Cys$\beta), 3.42-3.40(1 \mathrm{H}, \mathrm{m}, \mathrm{CH}), 3.59(2 \mathrm{H}, \mathrm{m}, \mathrm{Gly}-\alpha)$, 3.65-3.62 (1H, m, Glu- $\alpha), 4.28-4.26(1 \mathrm{H}, \mathrm{m}$, Cys$\alpha), 6.64\left(1 \mathrm{H}, \mathrm{s}, \mathrm{ArH}_{2^{\prime} / 6^{\prime}}\right), 6.72\left(1 \mathrm{H}, \mathrm{s}, \mathrm{ArH}_{2^{\prime} / 6^{\prime}}\right)$; ${ }^{13} \mathrm{C}-\mathrm{RMN}\left(\mathrm{D}_{2} \mathrm{O}, \delta\right): 17.5\left(\mathrm{CH}_{3}\right), 26.2\left(\mathrm{C}_{\mathrm{Glu}-\beta}\right)$, $31.4\left(\mathrm{C}_{\mathrm{Glu}-\gamma}\right), 34.9\left(\mathrm{C}_{\mathrm{Cys}-\beta}\right), 39.3\left(\mathrm{CH}_{2}\right), 42.3$ $\left(\mathrm{C}_{\mathrm{Gly}-\alpha}\right), 49.1(\mathrm{CH}), 53.2\left(\mathrm{C}_{\mathrm{Cys}-\alpha}\right), 54.1\left(\mathrm{C}_{\mathrm{Glu}-\alpha}\right)$, $117.4\left(\mathrm{C}_{\mathrm{Ar} 2^{\prime} / 6^{\prime}}\right), 119.4\left(\mathrm{C}_{\mathrm{Ar} 5^{\prime}}\right), 126.3\left(\mathrm{C}_{\mathrm{Ar} 2^{\prime} / 6^{\prime}}\right)$, $128.8\left(\mathrm{C}_{\mathrm{Ar}^{\prime}}\right), 144.2\left(\mathrm{C}_{\mathrm{Ar} 4^{\prime}}\right), 144.6\left(\mathrm{C}_{\mathrm{Ar} 3^{\prime}}\right), 172.1$ $\left(\mathrm{CO}_{\mathrm{Cys}}\right), 173.9\left(\mathrm{CO}_{\mathrm{Glu}}\right), 174.6\left(\mathrm{CO}_{\mathrm{Glu}}\right), 174.8$ $\left(\mathrm{CO}_{\mathrm{Gly}}\right)$; $\mathrm{MS}(\mathrm{FD}): \mathrm{m} / z 472.9340\left(\mathrm{MH}^{+}\right)$, calcu- lated for $\mathrm{C}_{19} \mathrm{H}_{29} \mathrm{~N}_{4} \mathrm{O}_{8} \mathrm{~S}: 473.1706$.

2-(GSH)- $\alpha$-MeDA (11): ${ }^{1} \mathrm{H}-\mathrm{NMR}\left(\mathrm{D}_{\mathbf{2}} \mathrm{O}, \delta\right)$ : $1.15\left(3 \mathrm{H}, \mathrm{t}, J=5.6, \mathrm{CH}_{3}\right), 1.96(2 \mathrm{H}, \mathrm{m}$, Glu- $\beta), 2.37-2.27(2 \mathrm{H}, \mathrm{m}, \mathrm{Glu}-\gamma), 2.96(2 \mathrm{H}, \mathrm{d}$, $\left.J=7.2, \mathrm{CH}_{2}\right), 3.14-3.06(1 \mathrm{H}, \mathrm{m}$, Cys- $\beta), 3.22-$ $3.18(1 \mathrm{H}, \mathrm{m}$, Сys- $\beta), 3.44-3.39(1 \mathrm{H}, \mathrm{m}, \mathrm{CH})$, $3.52(2 \mathrm{H}, \mathrm{s}, \mathrm{Gly}-\alpha), 3.61-3.60(1 \mathrm{H}, \mathrm{m}, \mathrm{Glu}-\alpha)$, $4.30-4.25(1 \mathrm{H}, \mathrm{m}$, Cys- $\alpha), 6.65(1 \mathrm{H}, \mathrm{d}, J=$ $\left.8.1, \mathrm{ArH}_{6^{\prime}}\right), 6.80\left(1 \mathrm{H}, \mathrm{d}, J=8.1, \mathrm{ArH}_{5^{\prime}}\right)$; ${ }^{13} \mathrm{C}-\mathrm{RMN}\left(\mathrm{D}_{2} \mathrm{O}, \delta\right)$ : $17.4\left(\mathrm{CH}_{3}\right), 26.2\left(\mathrm{C}_{\mathrm{Glu}-\beta}\right)$, $31.5\left(\mathrm{C}_{\mathrm{Glu}-\gamma}\right), 34.9\left(\mathrm{C}_{\mathrm{Cys}-\beta}\right), 38.7\left(\mathrm{CH}_{2}\right), 43.4$ $\left(\mathrm{C}_{\mathrm{Gly}-\alpha}\right), 49.3(\mathrm{CH}), 53.8\left(\mathrm{C}_{\mathrm{Cys}-\alpha}\right), 54.2\left(\mathrm{C}_{\mathrm{Glu}-\alpha}\right)$, $116.7\left(\mathrm{C}_{\mathrm{Ar}^{\prime} / 6^{\prime}}\right), 118.6\left(\mathrm{C}_{\mathrm{Ar} 2^{\prime}}\right), 121.9\left(\mathrm{C}_{\mathrm{Ar}^{\prime} / 6^{\prime}}\right)$, $131.9\left(\mathrm{C}_{\mathrm{Ar} 1^{\prime}}\right), 144.1\left(\mathrm{C}_{\mathrm{Ar} 4^{\prime}}\right), 147.6\left(\mathrm{C}_{\mathrm{Ar} 3^{\prime}}\right), 171.6$ $\left(\mathrm{CO}_{\mathrm{Gly} / \mathrm{Cys}}\right), 174.2\left(\mathrm{CO}_{\mathrm{Glu}}\right), 174.8\left(\mathrm{CO}_{\mathrm{Glu}}\right), 176.2$ $\left(\mathrm{CO}_{\mathrm{Gly} / \mathrm{Cys}}\right)$; MS (FD): $m / z 473.1940\left(\mathrm{MH}^{+}\right)$, calculated for $\mathrm{C}_{19} \mathrm{H}_{29} \mathrm{~N}_{4} \mathrm{O}_{8} \mathrm{~S}: 473.1706$.

5-(GSH)-N-Me- $\alpha$-MeDA (8). To a solution of $\mathbf{3}$ as hydrobromide salt $\left(2 \times 10^{-2} \mathrm{~g}, 7.6 \times\right.$ $\left.10^{-5} \mathrm{~mol}\right)$ in sodium phosphate buffer $(35 \mathrm{ml}, \mathrm{pH}$ $7.4,50 \mathrm{mM})$ at $25^{\circ} \mathrm{C}$ it was added mushroom tyrosinase $(3500$ units, $100 \mathrm{U} / \mathrm{ml}$ buffer). The solution became red, indicating the formation of $o$ quinone. GSH $\left(0.11 \mathrm{~g}, 3.82 \times 10^{-4} \mathrm{~mol}\right)$ was added and the solution red color changed with time to yellow ( $3 \mathrm{hrs}$ ). The solution was carefully concentrated by rotary evaporation without heating and dissolved in $1 \mathrm{ml}$ of water. The product purification was performed by reverse-phase RP-18 modified silica column chromatography using the following gradient: water $(200 \mathrm{ml}), 10 \%$ methanol $(\mathrm{MeOH})$ $(100 \mathrm{ml}), 20 \% \mathrm{MeOH}(50 \mathrm{ml})$ and $50 \% \mathrm{MeOH}$ (column wash). Each fraction was checked for the presence of adduct using a UV/vis detector. Fractions containing maxima at 232, 264 and $294 \mathrm{~nm}$ were separated and lyophilized to dryness. The product $8\left(3.2 \times 10^{-2} \mathrm{~g}\right)$ was obtained as oil in $74 \%$ yield; ${ }^{1} \mathrm{H}-\mathrm{NMR}\left(\mathrm{D}_{2} \mathrm{O}, \delta\right): 1.12(3 \mathrm{H}, \mathrm{d}, J=6.2$, $\left.\mathrm{CH}_{3}\right), 2.00(2 \mathrm{H}, \mathrm{q}, J=6.8$, Glu- $\beta), 2.36(2 \mathrm{H}, \mathrm{t}$, $J=7.3$, Glu- $\gamma), 2.58\left(3 \mathrm{H}, \mathrm{s}, \mathrm{N}-\mathrm{CH}_{3}\right), 2.60(1 \mathrm{H}$, s, $\left.\mathrm{CH}_{2}\right), 2.79-2.76\left(1 \mathrm{H}, \mathrm{m}, \mathrm{CH}_{2}\right), 3.07(1 \mathrm{H}, \mathrm{dd}$, $J=13.9$ and 8.6, Cys- $\beta), 3.25(1 \mathrm{H}, \mathrm{dd}, J=14.2$ and 4.5, Cys- $\beta), 3.31-3.30(1 \mathrm{H}, \mathrm{m}, \mathrm{CH}), 3.49(2 \mathrm{H}$, $\mathrm{d}, J=3.5$, Gly- $\alpha$ ), 3.64 (1H, t, $J=6$, Glu- $\alpha$ ), 4.29 $(1 \mathrm{H}, \mathrm{m}, \mathrm{Cys}-\alpha), 6.64\left(1 \mathrm{H}, \mathrm{s}, \operatorname{ArH}_{2^{\prime}} / 6^{\prime}\right), 6.71(1 \mathrm{H}$, $\left.\mathrm{s}, \mathrm{ArH}_{2^{\prime} / 6^{\prime}}\right) ;{ }^{13} \mathrm{C}-\mathrm{RMN}\left(\mathrm{D}_{2} \mathrm{O}, \delta\right): 14.9\left(\mathrm{CH}_{3}\right), 26.3$

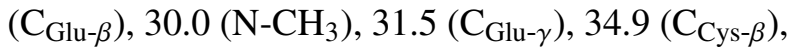
$37.4\left(\mathrm{CH}_{2}\right), 43.4\left(\mathrm{C}_{\mathrm{Gly}-\alpha}\right), 53.2\left(\mathrm{C}_{\mathrm{Cys}-\alpha}\right), 54.2$ $\left(\mathrm{C}_{\mathrm{Glu}-\alpha}\right), 53.5(\mathrm{CH}), 111.7\left(\mathrm{C}_{\mathrm{Ar} 2^{\prime} / 6^{\prime}}\right), 118.9\left(\mathrm{C}_{\mathrm{Ar} 5^{\prime}}\right)$, $126.1\left(\mathrm{C}_{\mathrm{Ar}^{\prime} / 6^{\prime}}\right), 128.3\left(\mathrm{C}_{\mathrm{Ar} 1^{\prime}}\right), 144.18\left(\mathrm{C}_{\mathrm{Ar}^{\prime}}\right)$, $144.7\left(\mathrm{C}_{\mathrm{Ar} 3^{\prime}}\right), 171.5\left(\mathrm{CO}_{\mathrm{Cys}-\alpha}\right), 174.0\left(\mathrm{CO}_{\mathrm{Glu}-\alpha}\right)$, $174.8\left(\mathrm{CO}_{\mathrm{Glu}-\gamma}\right), 176.1\left(\mathrm{CO}_{\mathrm{Gly}-\alpha}\right) ; \mathrm{MS}(\mathrm{FD}): \mathrm{m} / \mathrm{z}$ 
487.2291, calculated for $\mathrm{C}_{20} \mathrm{H}_{31} \mathrm{~N}_{4} \mathrm{O}_{8} \mathrm{~S}: 487.1863$.

5-(NAC)- $\alpha$-MeDA (9) and 2-( $N$-acetylcystein- $S$-yl)- $\alpha$-methyldopamine hydrobromide [2-(NAC)- $\alpha$-MeDA (12)]. To a solution of 4 as hydrobromide salt $\left(2 \times 10^{-2} \mathrm{~g}, 8.06 \times 10^{-5} \mathrm{~mol}\right)$ in sodium phosphate buffer $(30 \mathrm{ml}, \mathrm{pH} 7.4,50 \mathrm{mM})$ at $25^{\circ} \mathrm{C}$ it was added mushroom tyrosinase $(3960$ units, $132 \mathrm{U} / \mathrm{ml}$ buffer). The solution became red, indicating the formation of $o$-quinone. NAC $(6.5 \times$ $10^{-2} \mathrm{~g}, 4.04 \times 10^{-4} \mathrm{~mol}$ ) was added and the solution red color changed with time to light orange ( $2 \mathrm{hrs}$ ). At the terminus of the reaction $1 \mathrm{ml}$ of formic acid $88 \%$ was added and the solution was carefully concentrated by rotary evaporation without heating and dissolved in $1 \mathrm{ml}$ of formic acid $1 \%$. The product's purification was performed by reverse-phase RP-18 modified silica column chromatography using the following gradient: water $(200 \mathrm{ml}), 10 \% \mathrm{MeOH}$ $(100 \mathrm{ml}), 20 \% \mathrm{MeOH}(50 \mathrm{ml})$ and $50 \% \mathrm{MeOH}$ (column wash). Each fraction was checked for the presence of the adduct using a UV/vis detector. Fractions containing maxima at 264 and $294 \mathrm{~nm}$ (eluted with $10 \% \mathrm{MeOH}$ ) contained the adduct 12 and fractions containing maxima at 267 and $297 \mathrm{~nm}$ (eluted with $20 \% \mathrm{MeOH}$ ) contained the adduct 9 were separated and lyophilized to dryness. Compound $9\left(9.0 \times 10^{-3} \mathrm{~g}\right)$ was obtained as an oil in $28 \%$ and compound $\mathbf{1 2}\left(1.0 \times 10^{-3} \mathrm{~g}\right)$ also as an oil in $3.0 \%$.

5-(NAC)- $\alpha$-MeDA (9): ${ }^{1} \mathrm{H}-\mathrm{NMR}\left(\mathrm{D}_{2} \mathrm{O}, \delta\right)$ : 1.20-1.18 (3H, m, $\left.\mathrm{CH}_{3}\right), 1.78\left(3 \mathrm{H}, \mathrm{s}, \mathrm{CH}_{3} \mathrm{CO}\right)$, 2.74-2.62 (2H, m, $\left.\mathrm{CH}_{2}\right), 3.0-2.95(1 \mathrm{H}, \mathrm{m}$, Cys$\beta), 3.28(1 \mathrm{H}, \mathrm{d}, J=14$ and 2.8 , Cys- $\beta), 3.46-$ $3.45(1 \mathrm{H}, \mathrm{m}, \mathrm{CH}), 4.12-4.10(1 \mathrm{H}, \mathrm{m}, \mathrm{Cys}-\alpha), 6.67$ $\left(1 \mathrm{H}, \mathrm{s}, \mathrm{ArH}_{2^{\prime} / 6^{\prime}}\right), 6.79\left(1 \mathrm{H}, \mathrm{s}, \mathrm{ArH}_{2^{\prime} / 6^{\prime}}\right) ;{ }^{13} \mathrm{C}-$ $\mathrm{RMN}\left(\mathrm{D}_{2} \mathrm{O}, \delta\right)$ : $17.6\left(\mathrm{CH}_{3}\right), 21.9\left(\mathrm{CH}_{3} \mathrm{CO}\right), 36.0$ $\left(\mathrm{C}_{\mathrm{Cys}-\beta}\right), 39.3\left(\mathrm{CH}_{2}\right), 49.1(\mathrm{CH}), 54.7\left(\mathrm{C}_{\mathrm{Cys}-\alpha}\right)$, $117.2\left(\mathrm{C}_{\mathrm{Ar} 2^{\prime} / 6^{\prime}}\right), 120.5\left(\mathrm{C}_{\mathrm{Ar} 5^{\prime}}\right), 126.3\left(\mathrm{C}_{\mathrm{Ar} 2^{\prime} / 6^{\prime}}\right)$, $128.8\left(\mathrm{C}_{\mathrm{Ar}^{\prime}}\right), 143.9\left(\mathrm{C}_{\mathrm{Ar} 4^{\prime}}\right), 144.6\left(\mathrm{C}_{\mathrm{Ar} 3^{\prime}}\right), 173.5$ $\left(\mathrm{COCH}_{3}\right), 176.7(\mathrm{COOH}) ; \mathrm{MS}(\mathrm{FD}): m / z 329.1163$ $\left(\mathrm{MH}^{+}\right)$calculated for $\mathrm{C}_{14} \mathrm{H}_{21} \mathrm{~N}_{2} \mathrm{O}_{5} \mathrm{~S}: 329.1171$.

2-(NAC)- $\alpha$-MeDA (12): ${ }^{1} \mathrm{H}-\mathrm{NMR}\left(\mathrm{D}_{2} \mathrm{O}, \delta\right)$ : $1.14\left(3 \mathrm{H}, \mathrm{m}, \mathrm{CH}_{3}\right), 1.70$ and $1.67\left(3 \mathrm{H}, 2 \mathrm{~s}, \mathrm{COCH}_{3}\right)$, $3.00-2.91\left(3 \mathrm{H}, \mathrm{m}, \mathrm{CH}_{2}\right.$ and $\left.\mathrm{Cys}-\beta\right), 3.28-3.24(1 \mathrm{H}$, $\mathrm{m}$, Cys- $\beta$ ), 3.44-3.42 (1H, m, CH), 4.10-4.98 (1H, $\mathrm{m}$, Cys- $\alpha), 6.68\left(1 \mathrm{H}, \mathrm{d}, J=8.0, \mathrm{ArH}_{5^{\prime} / 6^{\prime}}\right), 6.79$ (1H, d, $\left.J=8.0, \mathrm{ArH}_{5^{\prime} / 6^{\prime}}\right)$. MS (FD): $m / z 329.1122$, calculated for $\mathrm{C}_{14} \mathrm{H}_{21} \mathrm{~N}_{2} \mathrm{O}_{5} \mathrm{~S}: 329.1171$.

5-(NAC)-N-Me- $\alpha$-MeDA (10). To a solution of $\mathbf{3}$ as hydrobromide salt $\left(2.5 \times 10^{-2} \mathrm{~g}, 9.54 \times\right.$ $\left.10^{-5} \mathrm{~mol}\right)$ in sodium phosphate buffer $(50 \mathrm{ml}, \mathrm{pH}$ $7.4,50 \mathrm{mM}$ ) at $25^{\circ} \mathrm{C}$ it was added mushroom ty- rosinase ( 3500 units, $132 \mathrm{U} / \mathrm{ml}$ buffer). The solution became red, indicating the formation of $o$-quinone. NAC $\left(7.8 \times 10^{-2} \mathrm{~g}, 4.77 \times 10^{-4} \mathrm{~mol}\right)$ was added and the solution red color changed with time to yellow $(2 \mathrm{hrs})$. At the terminus of the reaction $1 \mathrm{ml}$ of formic acid $88 \%$ was added and the solution yellow color change immediately to green. The solution was carefully concentrated by rotary evaporation without heating and dissolved in $1 \mathrm{ml}$ of formic acid $1 \%$. The product purification was performed by reverse-phase RP-18 modified silica column chromatography using the following gradient: water $(150 \mathrm{ml}), 10 \% \mathrm{MeOH}(150 \mathrm{ml}), 20 \% \mathrm{MeOH}$ $(50 \mathrm{ml})$ and $50 \% \mathrm{MeOH}$ (column wash). Each fraction was checked for the presence of adduct using a UV/vis detector. Fractions containing maxima at 232, 264 and $294 \mathrm{~nm}$ contained the adduct $\mathbf{1 0}$ were separated and lyophilized to dryness. Compound $\mathbf{1 0}$ $\left(1.3 \times 10^{-2} \mathrm{~g}, 3.08 \times 10^{-5} \mathrm{~mol}\right)$ was obtained as oil in $33 \% .{ }^{1} \mathrm{H}-\mathrm{NMR}\left(\mathrm{D}_{2} \mathrm{O}, \delta\right): 1.14(3 \mathrm{H}, \mathrm{d}, J=5.8$, $\left.\mathrm{CH}_{3}\right), 1.76\left(3 \mathrm{H}, \mathrm{s}, \mathrm{CH}_{3} \mathrm{CO}\right), 2.57\left(3 \mathrm{H}, \mathrm{s}, \mathrm{N}-\mathrm{CH}_{3}\right)$, 2.67-2.61 $\left(1 \mathrm{H}, \mathrm{m}, \mathrm{CH}_{2}\right), 2.78(1 \mathrm{H}, \mathrm{dd}, J=13.9$ and 6.4, $\left.\mathrm{CH}_{2}\right), 2.97(1 \mathrm{H}, \mathrm{dd}, J=14.1$ and 8.4 , Cys- $\beta)$, $3.27(1 \mathrm{H}, \mathrm{dd}, J=14.1$ and 3.8 , Cys- $\beta), 3.34(1 \mathrm{H}$, $\mathrm{dd}, J=13.0$ and 6.5, CH), 4.16-4.11 (1H, m, Cys$\alpha), 6.65\left(1 \mathrm{H}, \mathrm{s}, \mathrm{ArH}_{2^{\prime}} / 6^{\prime}\right), 6.78\left(1 \mathrm{H}, \mathrm{s}, \mathrm{ArH}_{2^{\prime}} / 6^{\prime}\right)$; ${ }^{13} \mathrm{C}-\mathrm{RMN}\left(\mathrm{D}_{2} \mathrm{O}, \delta\right): 15.0\left(\mathrm{CH}_{3}\right), 21.9\left(\mathrm{COCH}_{3}\right)$, $30.0\left(\mathrm{~N}-\mathrm{CH}_{3}\right), 36.0\left(\mathrm{C}_{\mathrm{Cys}-\beta}\right), 38.0\left(\mathrm{CH}_{2}\right), 54.7$ $\left(\mathrm{C}_{\mathrm{Cys}-\alpha}\right), 56.4(\mathrm{CH}), 117.2\left(\mathrm{C}_{\mathrm{Ar} 2^{\prime} / 6^{\prime}}\right), 120.6\left(\mathrm{C}_{\mathrm{Ar} 5^{\prime}}\right)$, $126.3\left(\mathrm{C}_{\mathrm{Ar}^{\prime} / 6^{\prime}}\right), 128.4\left(\mathrm{C}_{\mathrm{Ar}^{\prime}}\right), 143.9\left(\mathrm{C}_{\mathrm{Ar} 4^{\prime}}\right), 144.5$ $\left(\mathrm{C}_{\mathrm{Ar}^{\prime}}\right), 173.5\left(\mathrm{COCH}_{3}\right), 176.5(\mathrm{COOH}) ; \mathrm{MS}(\mathrm{FD})$ : $m / z 343.1353\left(\mathrm{MH}^{+}\right)$, calculated for $\mathrm{C}_{15} \mathrm{H}_{23} \mathrm{~N}_{2} \mathrm{O}_{5} \mathrm{~S}$ : 343.1328 .

Cyclic Voltammetry - Solutions for cyclic voltammetry measurements had concentrations between 0.8 to $1.5 \mathrm{mM}(0.9$ for $\mathbf{1}, 0.8$ for $\mathbf{4}, 1.5$ for 3, 0.8 for $\mathbf{7}, 0.9$ for $\mathbf{8}, 1.5$ for $\mathbf{9}, 0.9$ for $\mathbf{1 0}, 0.9$ for $\mathbf{1 1}$ and 1.5 for 13) in $50 \mathrm{mM}$ phosphate buffer ( $\mathrm{pH}$ 7.4), as supporting electrolyte. A solution of $\mathrm{K}_{4}\left[\mathrm{Fe}(\mathrm{CN})_{6}\right] . \quad 3 \mathrm{H}_{2} \mathrm{O} 1.5 \times 10^{-3} \mathrm{M}$ and $0.1 \mathrm{M}$ and $\mathrm{NaCl}$ was used for calibration. The sweep was performed between 1000 and $-500 \mathrm{mV}$.

Correlation of the Redox Potential of Compounds 3, 4 and 7 and Their Toxicity - The redox potential of compounds $\mathbf{3}, \mathbf{4}$ and $\mathbf{7}$ was plotted against their toxicity to rat cortical neurons. The toxicity data was obtained previously and published by our group, ${ }^{17)}$ and correspond to the neuronal viability of these cultures measured by the 3-(4,5dimethylthiazol-2yl)-2,5-diphenyl tetrazolium bromide (MTT) assay. 


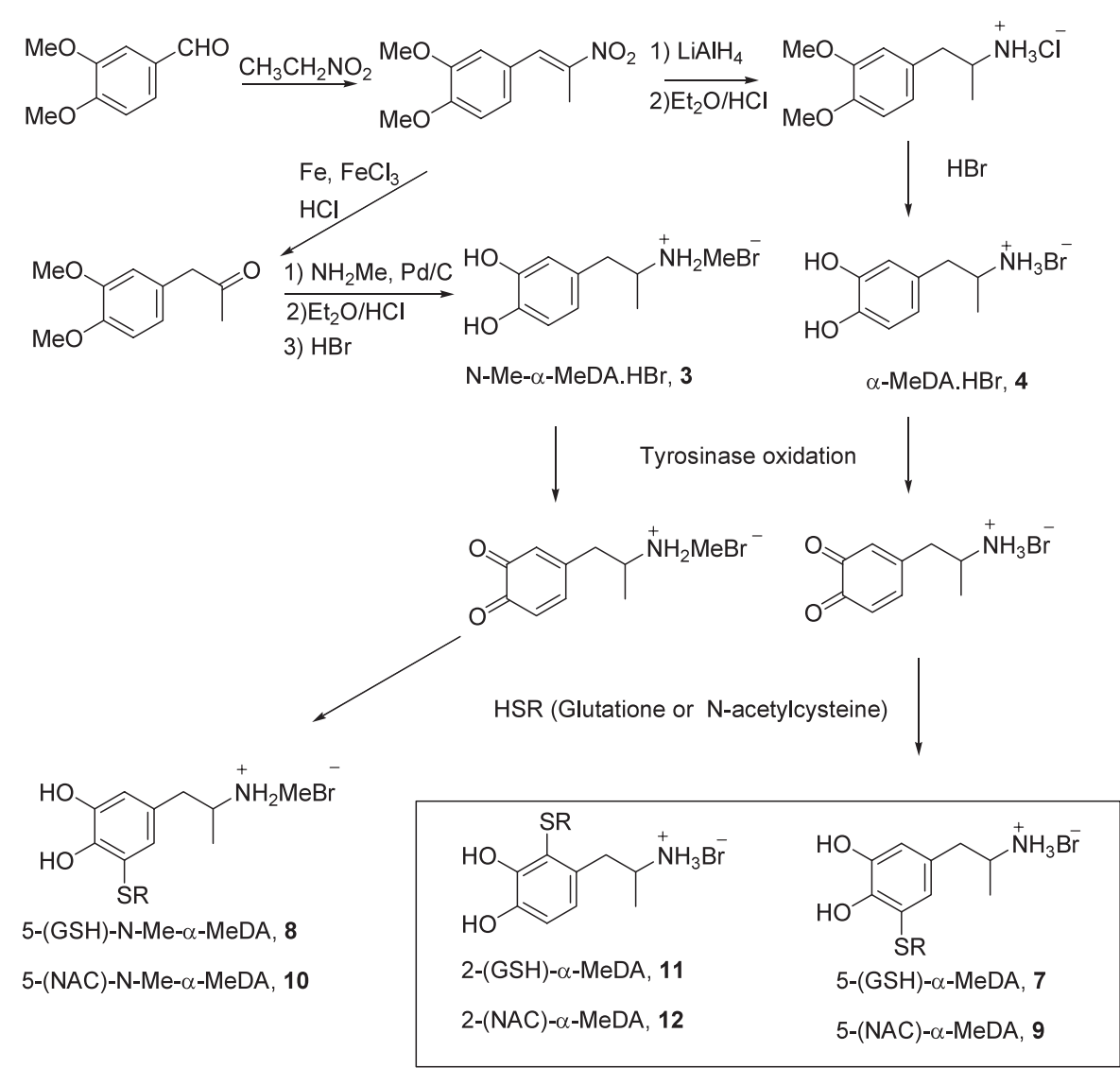

Fig. 2. Representative Scheme for the Preparation of MDMA Metabolites and Their Conjugates with GSH and NAC

\section{RESULTS}

\section{Chemical Synthesis}

Hydrobromide salts of N-Me- $\alpha$-MeDA (3) and $\alpha$-MeDA (4) were prepared following the procedure of Borgman $^{22)}$ and Pizarro ${ }^{23)}$ starting from the corresponding benzaldehyde and nitroethane. Their conjugate adducts with the bionucleophiles, GSH and NAC, 5-(GSH)- $\alpha$-MeDA (7), 5-(GSH)N-Me- $\alpha$-MeDA (8), 5-(NAC)- $\alpha$-MeDA (9), 5(NAC)-N-Me- $\alpha$-MeDA (10), were prepared by enzymatic oxidation according to previously published methods ${ }^{26,27)}$ with modifications. Although the synthesis of adducts $\mathbf{8}$ and $\mathbf{1 0}$ are reported on literature $^{26,28)}$ they omit the complete structural elucidation as we here describe.

The enzymatic oxidation of $\mathbf{4}$ followed by GSH or NAC addition allowed the isolation of the newly synthesized adducts 2-(GSH)- $\alpha$-MeDA (11) and 2(NAC)- $\alpha$-MeDA (12) (Fig. 2). Compound, 5-OH$\alpha$-MeDA (13) was likewise prepared. Structural determination was based on the two dimensional NMR experiments that allowed the clear attribution of all the protons. The aromatic pattern for the 5adducts (7-10) shows two singlets for each which agrees with the GSH and NAC covalently bonded at the 5-position. Also, the heteronuclear multiple bond correlation (HMBC) spectra showed the correlation between the aromatic $\mathrm{C} 5$ and the protons of cysteine $\beta-\mathrm{CH}_{2}$. As expected when the GSH or NAC are bonded to the 2 position the two remaining orto protons presents a pair of doublets with $\mathbf{J}$ $=8 \mathrm{~Hz}$. Mass spectrometry agrees in all cases with the monoadduct formation.

\section{Cyclic Voltammetry Studies}

The synthesized MDMA metabolites $\mathbf{3}$ and $\mathbf{4}$ (as hydrobromide salts), its adducts $\mathbf{7}$ to $\mathbf{1 1}$ and also the related compound $\mathbf{1 3}$, were subjected to cyclic voltammetry studies and the results compared with those observed for the parent compound MDMA. The cyclic voltammetry of these compounds was conducted in a phosphate buffer at $\mathrm{pH} 7.4(50 \mathrm{mM})$ at a sweep rate $(v)$ of $200 \mathrm{mV} \mathrm{s}^{-1}$. Table 1 presents the oxidation potential of MDMA and its tested human metabolites as well as the related compound 
Table 1. Oxidation Potential of MDMA and its Human Metabolites

\begin{tabular}{ccc}
\hline \hline Entry & Compound & $\begin{array}{c}\mathrm{E}_{\mathrm{p}} \\
(\mathrm{mV})\end{array}$ \\
\hline 1 & MDMA, 1 & $-^{a)}$ \\
2 & $\alpha-\mathrm{MeDA}, \mathbf{4}$ & 349 \\
3 & $\mathrm{~N}-\mathrm{Me}-\alpha-\mathrm{MeDA}, \mathbf{3}$ & 420 \\
4 & $5-(\mathrm{GSH})-\alpha-\mathrm{MeDA}, \mathbf{7}$ & 228 \\
5 & $5-(\mathrm{GSH})-\mathrm{N}-\mathrm{Me}-\alpha-\mathrm{MeDA}, \mathbf{8}$ & 231 \\
6 & $5-(\mathrm{NAC})-\alpha-\mathrm{MeDA}, \mathbf{9}$ & 258 \\
7 & 5-(NAC)-N-Me- $\alpha$-MeDA, 10 & 308 \\
8 & 2-(GSH)- $\alpha$-MeDA, 11 & 392 \\
9 & $5-\mathrm{OH}-\alpha-\mathrm{MeDA}, \mathbf{1 3}$ & 171 \\
\hline
\end{tabular}

a) Redox activity not found.

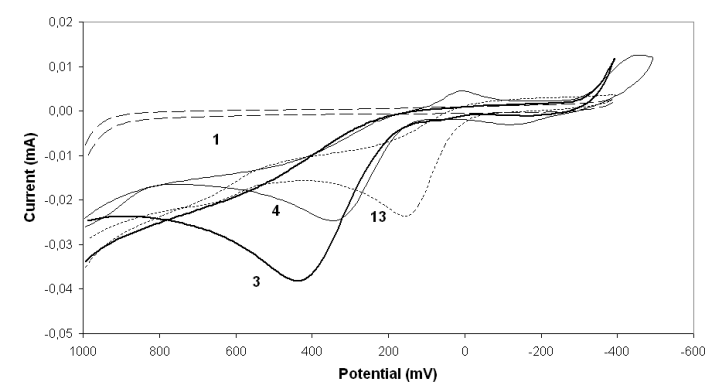

Fig. 3. Cyclic Voltammetry Curves of MDMA and Related Catecholamines [MDMA (1), N-Me- $\alpha$-MeDA.HBr (3), $\alpha$-MeDA.HBr (4), 5-OH- $\alpha$-MeDA (13)]

13. The anodic scans showed peaks that correspond to the oxidation of the catecholamine derivatives and their GSH or NAC conjugated adduct (Figs. 3 and 4). As previously described for adrenaline, in a neutral buffer, the correspondent cathodic peaks remained unobserved. ${ }^{29)}$ As seen in Fig. 3 no redox reactivity was measurable for MDMA when subjected to the same potentials as its metabolites. The methylene group blocking the two hydroxyl groups prevents the compound from adopting the quinone structure. Compound $\mathbf{1 3}$ shows the lower oxidation potential (Fig. 3) which is due to the several hydroxyl groups that activate the aromatic ring to oxidation. Similar effects were observed on other catecholic systems such as 3,4-dihydroxybenzoic acid and 3,4,5-trihydroxybenzoic acid. ${ }^{30)}$

The conjugation with GSH or NAC at the 5 position slightly reduced the oxidation potential when compared with the non-conjugated amines (Table 1 - representative examples are presented at Fig. 4). The effect of GSH conjugation at the 2position is less noticeable.

A correlation between the oxidability of com-

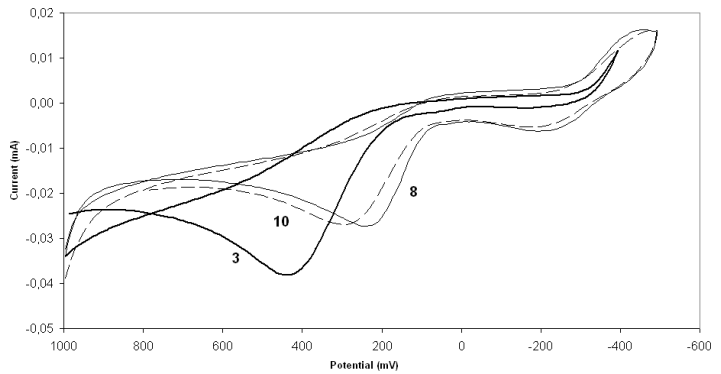

Fig. 4. Cyclic Voltammetry Curves of $N$-Methyl- $\alpha$-MethylDopamine and Their Adducts with GSH and NAC [NMe- $\alpha$-MeDA.HBr (3), 5-(GSH)-N-Me- $\alpha$-MeDA (8), 5(NAC)-N-Me- $\alpha$-MeDA (10)]

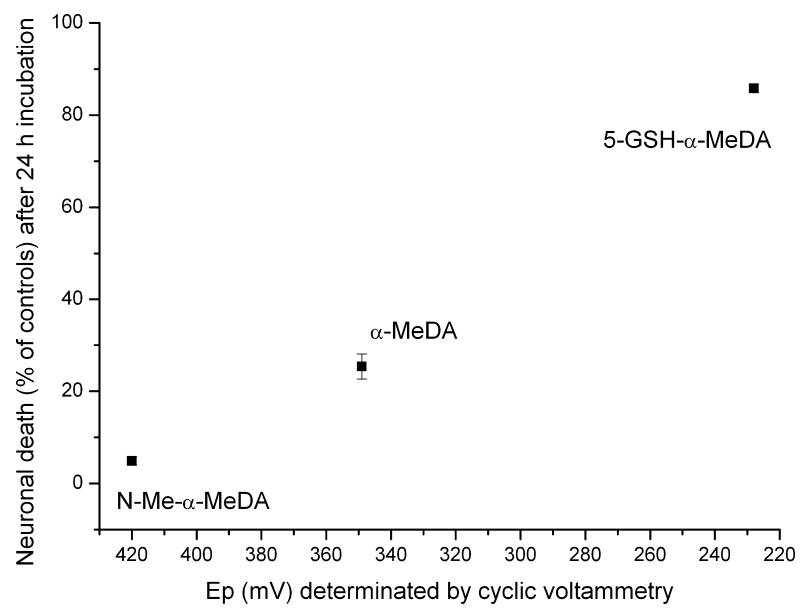

Fig. 5. Correlation between Oxidability and Toxicity to Rat Cortical Neuronal Cultures of MDMA Metabolites

pounds 3,4 and 7 and their ability to increase toxicity in rat cortical neuronal cultures can be observed on Fig. 5. The correlation was performed at the metabolite concentration of $200 \mu \mathrm{M} .{ }^{17)}$ Toxicity results for the concentration of $400 \mu \mathrm{M}$ showed a saturation phenomenon, therefore it was not possible to use this concentration for correlation (data not shown).

\section{DISCUSSION}

The key results of our study were: (a) synthesis and characterization of MDMA human metabolites, with special relevance for the newly synthesized $\mathbf{1 1}$ and 12 and, (b) evaluation of its redox properties and its relation with its potential to produce toxicity to rat cortical neurons.

Several studies failed to prove serotonergic neurotoxicity when MDMA and MDA where injected 
directly into the rat brain. ${ }^{5,31)}$ Since the serotonergic neurotoxicity could not occur after the direct brain administration of the drugs, it was postulated that systemic metabolism is probably important for the occurrence of neurotoxic events, ${ }^{6)}$ even though, the possible direct or indirect over-stimulation of serotonergic and dopaminergic neurons associated with hyperthermia can also contribute to the neurotoxic effects of non-metabolized MDMA., ${ }^{42}$

The metabolism of MDMA and MDA leads to highly oxidative compounds - the catecholamines. These compounds can auto-oxidize with resultant disturbances in vivo. The $o$-quinone intermediates thus formed can cause cellular lesions, i.e., via covalent binding (quinones undergo Michael addition) or generate ROS via redox cycling - both of which can lead to toxicity. ${ }^{10)}$

The nucleophilicity of the cysteine sulfydryl groups renders protein and non-protein sulfydryls preferential targets for the quinone intermediates of the MDMA and MDA-metabolites. GSH is the major non-protein sulfydryl present in cells, and the reaction of it's SH group with quinones prevents the occurrence of irreversible modification of other intracellular nucleophilic sites. However, some polyphenolic-GSH conjugates, and their metabolites, retain the electrophilic and redox properties of the parent polyphenol. ${ }^{33,34)}$ Indeed, the reactivity of the thioether metabolites may exceed that of the parent polyphenol. In biological media, $\alpha$ MeDA undergoes oxidation to the corresponding $o$-quinone, which is conjugated with $\mathrm{GSH}^{26,35)}$ to form 5-(GSH)- $\alpha$-MeDA. This metabolite is readily oxidized to the $o$-quinone-GSH derivate, followed by subsequent addition of a second molecule of GSH to form 2,5-bis(glutathion-S-yl)- $\alpha$-MeDA. ${ }^{16}$ ) Capela et al. ${ }^{17)}$ have shown that 5-(GSH)- $\alpha$-MeDA has a potent toxic effect in rat cortical neurons.

Fast-sweep electrochemical techniques were previously applied to the study of the oxidation pathways of catecholamines in vitro. These techniques allowed the positive identification of the transient intermediates, i.e., the open-chain $o$ quinones, and the precise determination of the rate of intramolecular cyclization to the substituted indole as well as its subsequent oxidation to the aminochrome. ${ }^{14)}$ In accordance Carvalho et al. ${ }^{20)}$ have demonstrated in vitro that the concentration of $\mathrm{N}-\mathrm{Me}-\alpha$-MeDA and $\alpha$-MeDA decreases over time in biological media, due to their oxidation to the correspondent aminochromes.

Electrochemical oxidation of the catechol group has also been studied in the presence of secondary amines ${ }^{36,37)}$ and mercaptotriazole ${ }^{38)}$ as nucleophiles. Common to these reports is the presence of one anodic and a corresponding cathodic peak on the cyclic voltammetry record of the catechol in buffered solution. These findings correspond to the transformation of the catechol to the corresponding $o$-benzoquinone and vice-versa, within a quasi reversible two electron transfer process. ${ }^{36,37)}$ The oxidation of the catechol in the presence of a nucleophile (secondary amines or thiols) results in a 1,4-Michael addition reaction. The resulting compounds (amines and thio substituted catechols) are more easily oxidized than the parent starting molecule by virtue of the presence of an extra electron-donating group. ${ }^{38)}$

Recent studies on the electrochemical oxidation-reduction processes of adrenaline, studied by multi-mode in situ spectroelectrochemistry, found that the redox pathways were related to the $\mathrm{pH}$ of the solution, the potential window and the oxygen dissolved in the medium. ${ }^{39)}$ The formation of an $o$-quinone was invoked. These authors ${ }^{29,40)}$ observed the scavenging of the $o$-quinone by $L$-cysteine with formation of adducts and also subsequent oxidation of these cysteinyl conjugates originate $o$-quinones that could further react with free $L$-cysteine yielding the corresponding bis-adducts. A similar behavior was observed for dopamine (DA), ${ }^{15)}$ although an electrochemical-chemical-electrochemical (ECE) reaction mechanism was proposed for the DA electrochemical oxidation with a subsequent polymerization of the resulting 5,6-indolequinone.

At the present working conditions, $\mathrm{pH} 7.4$, the deprotonation of the $o$-quinone (14), formed upon oxidation $\left(2 \mathrm{e}^{-}, 2 \mathrm{H}^{+}\right)$of catecholamines, yields the neutral $o$-quinone (15) that undergo an intramolecular cyclization reaction (1,4-Michael addition) to give 5,6-dihydroxyindoline (16). In solution this compound is oxidized by $o$-quinone (14) to the corresponding $p$-quinone imine (17) also designated as aminochrome (Fig. 6). The reaction sequence occurs so fast that, after each scan reversal, a peak corresponding to the reversible reduction of $o$-quinone was never observed in the cyclic voltammograms for all the tested compounds. This observation has precedence in the literature. ${ }^{14,29)}$ The only peak observed on the initial anodic sweep corresponds to the oxidation of the catecholamines and their GSH and NAC adducts to 14 (Table 1) that rapidly deprotonates and cyclises to $\mathbf{1 6}$. This is in turn rapidly 


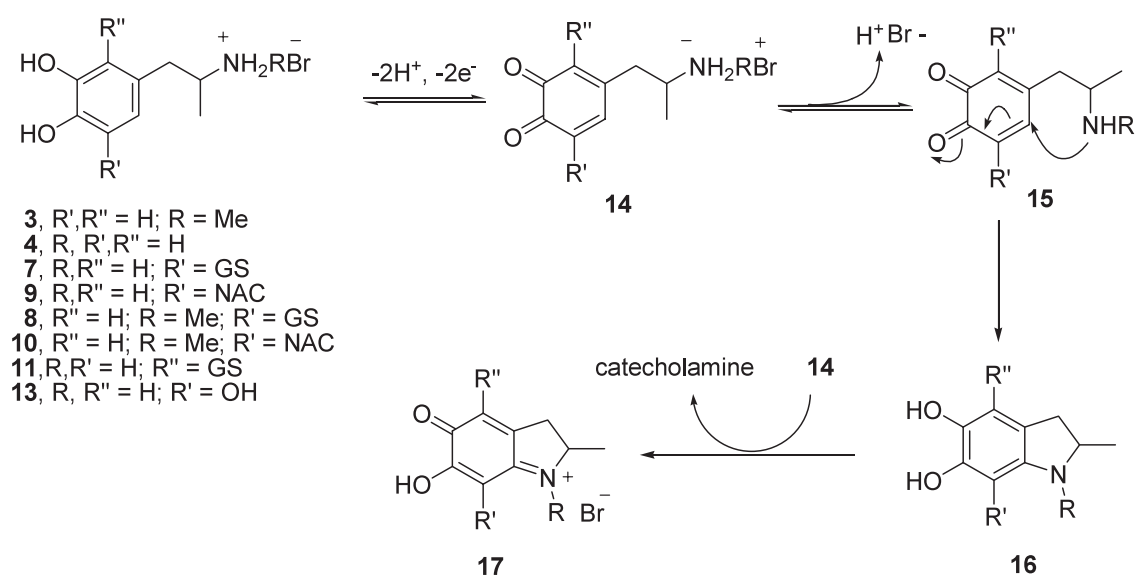

Fig. 6. Proposed Behavior of Catecholamines ${ }^{29)}$ upon Cyclic Voltammetry

chemically oxidized to $\mathbf{1 7}$. Only for compound 4 a couple of low intensity peaks $\left(\mathrm{E}_{\mathrm{p}}^{\circ}=-100 \mathrm{mV}\right)$, indicating a reversible process between $\mathbf{1 6}$ and 17, were observed. For this particular case the rate of chemical reaction is slower, allowing a reversible electrochemical redox reaction between $\mathbf{1 6}$ and $\mathbf{1 7}$ to be observed ( $c f$. Fig. 3).

According to our results, $\alpha-\operatorname{MeDA}(4)$ is more easily oxidized than N-Me- $\alpha$-MeDA (3). Indeed, whereas the $E_{p}$ value for 3 is $420 \mathrm{mV}$, the corresponding $E_{p}$ for 4 is $349 \mathrm{mV}$ i.e., a difference of $71 \mathrm{mV}$. Probably, the most obvious reason for this event may be the difference in the $\mathrm{pK}_{\mathrm{a}}$ of $\mathbf{4}$, a primary amine, versus $\mathbf{3}$, a secondary amine, bearing higher basicity. ${ }^{41)}$ It's known from literature ${ }^{42,43)}$ that $\mathrm{OH}-\mathrm{N}$ hydrogen bonding can have a profound effect in altering the oxidation potential of enols to lower values. At the $\mathrm{pH}$ of 7.4 used for the cyclic voltammetry experiments, $\mathbf{3}$ should exist preferentially as its hydrochloride salt and $\mathbf{4}$, partially in its free amine form, could be involved in intermolecular hydrogen bonding responsible for lowering the $\mathrm{E}_{\mathrm{p}}$. However we should not exclude the involvement of other factors as solvation effects that may result in a higher stabilization of $\mathbf{3}$ in relation to 4 .

From the results of Table 1 it is possible to conclude that the conjugation with GSH or NAC at the 5 position reduced the oxidation potential when compared with the non-conjugated amines. When the catechol moiety becomes attached to compounds like GSH or NAC the presence of a third heteroatom on the aromatic ring is the main contribution to the reduction of the redox potential and accounts for the difference on the $E_{p}$ observe for the cathecol thioeter adducts versus the parent catecholamines. In fact the highest value for the difference on the $E_{p}$ that is observed for the glutathione adducts $(-189$ and $-121 \mathrm{mV}$ for $\mathbf{8} v s .3$ and $\mathbf{7 v s . 4}$ ) highlights this explanation.

The voltammetric curve obtained for newly synthesized thioether adduct $\mathbf{1 1}$ shows that 2-GSH$\alpha$-MeDA (11) is more resistant to the oxidation than the parent catecholamine $4(+43 \mathrm{mV}$ for 4 vs. 11). Since 2 -aducts are more stereochemical constrained than 5 adducts the adopted conformation of GSH chain should promote the stabilization of the catechol structure and prevent its oxidation to the quinone as described for the catechol NCQ-436, a metabolite of the antipsychotic remoxipride. ${ }^{44)}$

Noteworthy, the lower oxidation potential observed for the 5-GSH adducts of $\alpha$-MeDA relative to the parent catecholamine correlates well with the higher toxicity of this adduct in rat cortical neurons. Accordingly, unlike N-Me- $\alpha$-MeDA and $\alpha$ MeDA, their systemically formed thioether conjugates are easily transported across the blood-brain barrier. ${ }^{28)}$ Studies in vivo show that intracerebroventricular (ICV) injections of 5-(GSH)- $\alpha$-MeDA into rats produced neurobehavioral changes characteristic of peripheral administration of MDMA/MDA as well as acute increases in brain 5-HT and DA concentrations ${ }^{45}$ ) and produced prolonged depletions in 5-HT similar to those obtained after peripheral administration of MDA and MDMA. ${ }^{46)}$ Moreover, recent experiments using in vivo microdialysis have provided direct evidence for the presence of GSH and NAC conjugates of MDMA metabolites in the brain after in vivo s.c. administration of MDMA. ${ }^{28)}$ This accounts for the importance that voltammetry studies may assume in predicting the potential neurotoxicity of MDMA and MDA-metabolites. It should be nevertheless emphasized that not only di- 
rect MDMA-metabolites toxicity contribute to the toxic events. Other factors, like the possible direct or indirect over-stimulation of serotonergic and dopaminergic neurons associated with hyperthermia also contribute to the neurotoxic effects of nonmetabolized MDMA.

In conclusions, oxidation of catecholamines can lead to the rapid formation of electrophilic and redox active quinones. These species are susceptible to alkylation by cellular nucleophiles (GSH, proteins, and DNA) and can undergo further oxidation. Our results show that there is a significant correlation between the redox behavior of the MDMA and MDA metabolites and their respective toxicity to rat cortical neurons.

Acknowledgments This work was supported by REQUIMTE Associated Laboratory, and "Fundação Calouste Gulbenkian" (Ref. FCG 10/04). J.P.C. was the recipient of a Ph. D. grant from "Fundação para a Ciência e Tecnologia" (Ref.

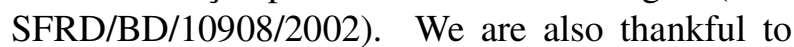
the Photochemistry Group of REQUIMTE/CQFB, Departamento de Química, FCT, Universidade Nova de Lisboa, 2829-516 Caparica, Portugal for the use of the potentiostat apparatus.

\section{REFERENCES}

1) Kenny, P. J. and Markou, A. (2004) The ups and downs of addiction: role of metabotropic glutamate receptors. Trends Pharmacol. Sci., 25, 265-272.

2) Commins, D. L., Vosmer, G., Virus, R. M., Woolverton, W. L., Schuster, C. R. and Seiden, L. S. (1987) Biochemical and histological evidence that methylenedioxymethylamphetamine (MDMA) is toxic to neurons in the rat-brain. J. Pharmacol. Exp. Ther., 241, 338-346.

3) Ricaurte, G., Bryan, G., Strauss, L., Seiden, L. and Schuster, C. (1985) Hallucinogenic amphetamine selectively destroys brain-serotonin nerve-terminals. Science, 229, 986-988.

4) Green, A. R., Mechan, A. O., Elliot, J. M., O'Shea, E. and Colado, M. I. (2003) The Pharmacology and Clinical Pharmacology of 3,4Methylenedioxymethamphetamine (MDMA, "Ecstasy"). Pharmacol. Rev., 55, 463-508.

5) Esteban, B., O'Shea, E., Camarero, J., Sanchez, V., Green, A. R. and Colado, M. I. (2001) 3,4-Methylenedioxymethamphetamine induces monoamine release, but not toxicity, when ad- ministered centrally at a concentration occurring following a peripherally injected nenrotoxic dose. Psychopharmacology, 154, 251-260.

6) Monks, T. J., Jones, D. C., Bai, F. J. and Lau, S. S. (2004) The role of metabolism in 3,4(+/-)-methylenedioxyamphetamine and 3,4-(+/-)methylenedioxymethamphetamine (ecstasy) toxicity. Ther. Drug Monit., 26, 132-136.

7) Schmidt, C. J. and Taylor, V. L. (1988) Direct central effects of acute methylenedioxymethamphetamine on serotonergic neurons. Eur. J. Pharmacol., 156, 121-131.

8) Kumagai, Y., Lin, L. Y., Hiratsuka, A., Narimatsu, S., Suzuki, T., Yamada, H., Oguri, K., Yoshimura, H. and Cho, A. K. (1994) Participation Of Cytochrome P450-2b And P450-2d Isozymes In The Demethylenation Of Methylenedioxymethamphetamine Enantiomers By Rats. Mol. Pharmacol., 45, 359-365.

9) Lim, H. K. and Foltz, R. L. (1988) Invivo and invitro metabolism of 3,4(methylenedioxy)methamphetamine in the rat identification of metabolites using an ion trap detector. Chem. Res. Toxicol., 1, 370-378.

10) Bolton, J. L., Trush, M. A., Penning, T. M., Dryhurst, G. and Monks, T. J. (2000) Role of quinones in toxicology. Chem. Res. Toxicol., 13, 135-160.

11) Remião, F., Carvalho, M., Carmo, H., Carvalho, F. and Bastos, M. L. (2002) $\mathrm{Cu}^{2+}$-induced isoproterenol oxidation into isoprenochrome in adult rat calcium-tolerant cardiomyocytes. Chem. Res. Toxicol., 15, 861-869.

12) Kovacic, P. (2005) Unifying mechanism for addiction and toxicity of abused drugs with application to dopamine and glutamate mediators: Electron transfer and reactive oxygen species. Med. Hypotheses, 65, 90-96.

13) Kovacic, P. and Cooksy, A. L. (2005) Unifying mechanism for toxicity and addiction by abused drugs: electron transfer and reactive oxygen species. Med. Hypotheses, 64, 357-366.

14) Hawley, M. D., Tatawawa, S. V., Piekarsk, S. and Adams, R. N. (1967) Electrochemical studies of oxidation pathways of catecholamines. J. Am. Chem. Soc., 89, 447-450.

15) Li, Y. L., Liu, M. L., Xiang, C. H., Xie, Q. J. and Yao, S. Z. (2006) Electrochemical quartz crystal microbalance study on growth and property of the polymer deposit at gold electrodes during oxidation of dopamine in aqueous solutions. Thin Solid Films, 497, 270-278.

16) Miller, R. T., Lau, S. S. and Monks, T. J. 
(1997) 2,5-Bis-(glutathion-S-yl)-alpha-methyldopamine, a putative metabolite of (+/-)-3,4-methylenedioxyamphetamine, decreases brain serotonin concentrations. Eur. J. Pharmacol., 323, 173-180.

17) Capela, J. P., Meisel, A., Abreu, A. R., Branco, P. S., Ferreira, L. M., Lobo, A. M., Remiao, F., Bastos, M. L. and Carvalho, F. (2006) Neurotoxicity of ecstasy metabolites in rat cortical neurons, and influence of hyperthermia. J. Pharmacol. Exp. Ther, 316, 53-61.

18) Carvalho, M., Hawksworth, G., Milhazes, N., Borges, F., Monks, T., Fernandes, E., Carvalho, F. and Bastos, M. D. L. (2002) Role of metabolites in MDMA (ecstasy)-induced nephrotoxicity: an in vitro study using Rat and Human renal proximal tubular cells. Arch. Toxicol., 76, 581-588.

19) Carvalho, M., Remião, F., Milhazes, N., Borges, F., Fernandes, E., Carvalho, F. and Bastos, M. L. (2004) The toxicity of $N$-methyl- $\alpha$-methyldopamine to freshly isolated rat hepatocytes is prevented by ascorbic acid and $N$-acetylcysteine. Toxicology, 200, 193-203.

20) Carvalho, M., Remiao, F., Milhazes, N., Borges, F., Fernandes, E., Monteiro, M. D., Goncalves, M. J., Seabra, V., Amado, F., Carvalho, F. and Bastos, M. L. (2004) Metabolism is required for the expression of ecstasy-induced cardiotoxicity in vitro. Chem. Res. Toxicol., 17, 623-632.

21) Armarego, W. L. F. and Perrin, D. D. (1996) Purification of Laboratory Chemicals, Oxford, Butterworth-Heinemann.

22) Borgman, R. J., Baylor, M. R., McPhilli.Jj and Stitzel, R. E. (1974) $\alpha$-Methyldopamine Derivative Synthesis and Pharmacology. J. Med. Chem., 17, 427-430.

23) Pizarro, N., de la Torre, R., Farre, M., Segura, J., Llebaria, A. and Joglar, J. (2002) Synthesis and capillary electrophoretic analysis of enantiomerically enriched reference standards of MDMA and its main metabolites. Bioorg. Med. Chem., 10, 1085-1092.

24) Shulgin, A. T. (1964) Psychotomimetic amphetamines: methoxy 3,4-dialkoxyamphetamines. Experientia, 20, 366-367.

25) Ho, B. T., McIsaac, W. M., An, R., Tansey, L. W., Walker, K. E., Englert, L. F. and Noel, M. B. (1970) Analogs of $\alpha$-methylphenethlamine (amphetamine). 1. Synthesis and pharmacological activity of some methoxy and/or methyl analogs. J. Med. Chem., 13, 26-30.

26) Hiramatsu, M., Kumagai, Y., Unger, S. E. and Cho, A. K. (1990) Metabolism of methylenedioxymethamphetamine - formation of dihydroxymethamphetamine and a quinone identified as its glutathione adduct. J. Pharmacol. Exp. Ther, 254,
$521-527$.

27) Miller, R. T., Lau, S. S. and Monks, T. J. (1995) Metabolism of 5-(glutathione- $S$-yl)- $\alpha$ methyldopamine following intracerebroventricular administration to male Sprague-Dawley rats. Chem. Res. Toxicol., 8, 634-641.

28) Jones, D. C., Duvauchelle, C., Ikegami, A., Olsen, C. M., Lau, S. S., de la Torre, R. and Monks, T. J. (2005) Serotonergic neurotoxic metabolites of ecstasy identified in rat brain. J. Pharmacol. Exp. Ther., 313, 422-431.

29) Shen, X. M. and Dryhurst, G. (1996) Influence of L-cysteine on the oxidation chemistry of (-)epinephrine: Formation of cysteinyl conjugates and novel dihydrobenzothiazines. Bioorg. Chem., 24, 340-357.

30) Ball, E. G. and Chen, T.-T. (1933) Studies on oxidation-reduction. XX. Epinephine and related compounds. J. Biol. Chem., 102, 691-719.

31) Paris, J. M. and Cunningham, K. A. (1992) Lack of serotonin neurotoxicity after intraraphe microinjection of (+)-3,4-methylenedioxymethamphetamine (MDMA). Brain Res. Bull., 28, 115-119.

32) Capela, J. P., Ruscher, K., Lautenschlager, M., Freyer, D., Dirnagl, U., Bastos, M. L., Meisel, A. and Carvalho, F. (2006) Ecstasy-induced cell death in cortical neuronal cultures is 5HT2A-receptordependent and potentiated under hyperthermia. $\mathrm{Neu}$ roscience, 139, 1069-1081.

33) Monks, T. J. and Lau, S. S. (1997) Biological reactivity of polyphenolic-glutathione conjugates. Chem. Res. Toxicol., 10, 1296-1313.

34) Monks, T. J. and Lau, S. S. (1998) The pharmacology and toxicology of polyphenolic-glutathione conjugates. Аnnu. Rev. Pharmacol. Toxicol., 38, 229-255.

35) Patel, N., Kumagai, Y., Unger, S. E., Fukuto, J. M. and Cho, A. K. (1991) Transformation of dopamine and $\alpha$-methyldopamine by $\mathrm{Ng} 108$-15-cells - formation of thiol adducts. Chem. Res. Toxicol., 4, 421426.

36) Kiani, A., Raoof, J. B., Nematollahi, D. and Ojani, R. (2005) Electrochemical study of catechol in the presence of dibuthylamine and diethylamine in aqueous media: Part 1. Electrochemical investigation. Electroanalysis, 17, 1755-1760.

37) Nematollahi, D., Tammari, E., Sharifi, S. and Kazemi, M. (2004) Mechanistic study of the oxidation of catechol in the presence of secondary amines by digital simulation of cyclic voltammograms. Electrochim. Acta, 49, 591-595.

38) Shahrokhian, S. and Amiri, M. (2005) Mercaptotriazole as a nucleophile in addition to o-quinone 
electrochemically derived from catechol: application to electrosynthesis of a new group of triazole compounds. Electrochem. Commun., 7, 68-73.

39) Cui, H., Wu, L. S., Chen, J. and Lin, X. Q. (2001) Multi-mode in situ spectroelectrochemical studies of redox pathways of adrenaline. J. Electroanal. Chem., 504, 195-200.

40) Shen, X. M. and Dryhurst, G. (1997) Further insights into the oxidation chemistry of norepinephrine and epinephrine in the presence of cysteine. Bioorg. Chem., 25, 130-153.

41) Solomons, T. W. G. and Fryhle, C. B. (2004) Organic Chemistry, Wiley.

42) Fang, Y., Liu, L., Feng, Y., Li, X. S. and Guo, Q. X. (2002) Effects of hydrogen bonding to amines on the phenol/phenoxyl radical oxidation. J. Phys. Chem. A, 106, 4669-4678.

43) Lal, M., Langels, A., Deiseroth, H. J., Schlirf, J. and Schmittel, M. (2003) Role of hydrogen bonding in the oxidation potential of enols. J. Phys. Org. Chem., 16, 373-379.

44) Erve, J. C. L., Svensson, M. A., von Euler-Chelpin, H. and Klasson-Wehler, E. (2004) Characterization of glutathione conjugates of the remoxipride hydroquinone metabolite NCQ-344 formed in vitro and detection following oxidation by human neutrophils. Chem. Res. Toxicol., 17, 564-571.

45) Bai, F. J., S. S. Lau and Monks, T. J. (1999) $\mathrm{G}$;itathione and $\mathrm{N}$-acetylcysteine conjugates of alpha-methyldopamine produce serotonergic neurotoxicity: Possible role in methylenedioxyamphetamine-mediated neurotoxicity. Chem. Res. Toxicol., 12, 1150-1157.

46) Miller, R. T., S. S. Lau and Monks, T. J. (1997) 2,5Bis-(glutathion-S-yl)-alpha-methyldopamine, a putative metabolite of (+/-)-3,4-methylenedioxyamphetamine, decreases brain serotonin concentrations. Eur. J. Pharmacol., 323, 173-180. 